Mansoura University

Faculty of Tourism and Hotels

\title{
The Effectiveness of Public Relations Activities in THE EGYPTIAN HOTELS: AN EXPLORATORY STUDY
}

Extract of Master Thesis

\begin{tabular}{|c|c|}
\hline \multicolumn{2}{|c|}{ By } \\
\hline Shrook Fawzy Abdallah & Dr/Sherif Gamal Saad \\
\hline Master Researcher & Ass. Prof of Hotel management- \\
\hline Faculty of Tourism and Hotels - & $\begin{array}{c}\text { Faculty of Tourism and Hotels - } \\
\text { Mansoura University }\end{array}$ \\
\hline
\end{tabular}

RESEARCH JOURNAL OF THE FACULTY OF TOURISM AND HOTELS

MANSOURA UNIVERSITY

ISSUE NO. 6, DECEMBER. 2019 
- The Effectiveness of Public Relations Activities in the Egyptian Hotels: An exploratory study 


\section{The Effectiveness of Public Relations Activities in THE EGYPTIAN HOTELS: AN EXPLORATORY STUDY}

Shrook Fawzy Abdallah ${ }^{1}$

\section{Abstract}

In the light of the increasing international interest of public relations (PR) in the hospitality industry, this research was conducted with the aim of studying the effectiveness of public relations department in the Egyptian hotels. For this purpose, an empirical study has been conducted on a sample of five-star and four-star hotel employees at Greater Cairo to identify the activities and the tools used by this department. The study also assessed the effectiveness of these activities and the importance of these tools. This study employed in-depth interviews with PR practitioners at hotels as the data collection instrument. Twenty two interviews were conducted with a convenience sample from the five and four-star hotels in Greater Cairo. The findings of the study showed that public relations departments at the Egyptian hotels are very effective in forming the hotels' image, reputation and competitive advantages.

Keywords: Public relations, Hotel's image, Hotel's reputation, Media relations, Corporate social responsibility. 
- The Effectiveness of Public Relations Activities in the Egyptian Hotels: An exploratory study

\section{فاعلية أنشطة العلاقات العاهة بالفنادق المصرية: دراسة استكشافية}

تعتبر العلاقات العامـة من الأمور الهامة والحيوية للغاية يِّ اتخاذ القرارات

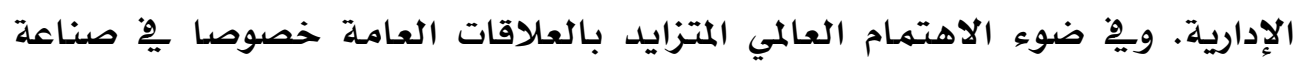
الضيافة ، فقد قام هذا البحث بدراسة فاعلية قسم العلاقات العامة بالفنادق المصرية.

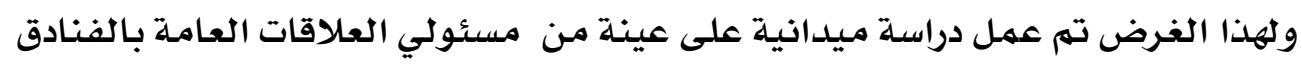

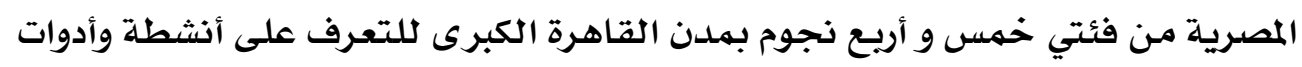

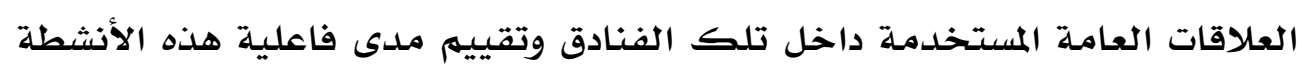

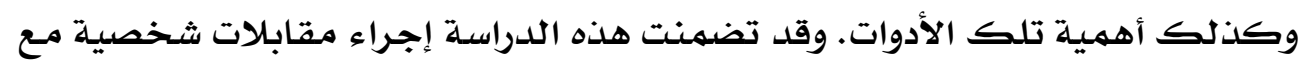

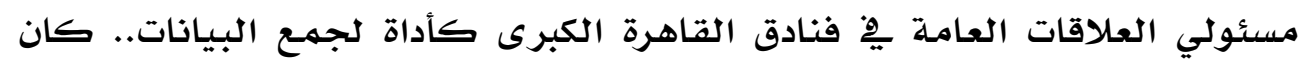

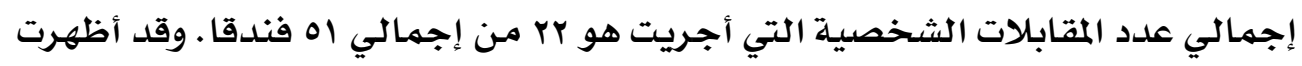

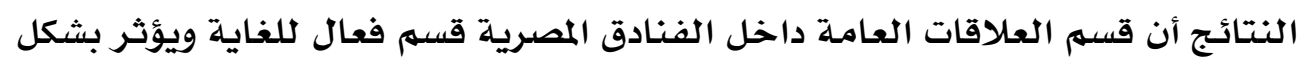
إيجابي على صورة الفندق وسمعته وميزته التنافسية. وقد قدمت خاتمة البحث التهل مجموعة من التوصيات العملية المهمة بِّه مجال إدارة الفنادق. 


\section{Introduction}

Public relations is a deliberate, planned, and sustained effort to establish and maintain mutual understanding between an organization and its publics (Jethwaney \& Sarkar, 2000). One of the important roles of public relations is the creation and maintaining good image of the organization. Public relations department has a responsibility to handle all the issues which are related to internal and external public. Internal public is the public inside the organization or institution, such as: shareholder, management, executive, employee and employee's family. External public is the people outside the organization or institution, such as: customers, society, government, press, bank and other organization or institution (Jethwaney \& Sarkar, 2000). The title "public relations" is an accurate description, although frequently misinterpreted and over-simplified, it is the relations between a public body (public company, organization or government) and its publics (Bates, 2006).

Daft (2001) stated that "Public relations is a means of controlling environmental resources through inter-organizational linkages". Besides, public relations concept refers to the art and social science of analyzing trends, forecasting their consequences, counseling organization leaders and accomplishing planned programs of action which will serve both the organizations and the public interest (Warnaby et al., 2002). Furthermore, public relations concept refers to the management function that creates and maintains mutually advantageous relationships between an organization and the publics on whom its success or failure depends (Broom, 2009). Moreover, it is the work of the organization management, which influences the visions of the audience (Lawrence et al., 2014).

As with any marketing activity in the hospitality industry, public relations is integrated with the rest of promotional efforts of the organization and it is clearly related to more widespread 
objectives of the entity itself (Belch et al., 2001). Moreover, Marconi (2004) agreed with Grates (1995) that a public relation is a major factor in the way the organization's image comes into focus. Because of public relations practitioners' important role in building and maintaining the image of their organization, they are often described as image- makers. It is believed that hotel image plays an important role on a customer in making the decision to use a hotel.

The main aim of this research is to study the effectiveness of public relations activities in the Egyptian hotels. The objectives of the study are: To identify the public relations activities in the Egyptian hotels, and to assess the importance and impact of public relations activities on the hotel's image.

\section{Literature review}

Bruning et al. (2000) illustrated that the relational management perspective transfers public relations practice from "influencing public opinion using communication messages" to "set of representative communication key messages and organizational behaviors to start, foster, and maintain mutually beneficial organization's public relations". In addition, work by Grunig et al. (2002) emphasized the organizational behavior and attitude in relationship-building, that is to say, "what an organization does more than what it says has a strong impact on the way people think about it and what they say about it and the relationship they have with that organization". In this way, public relations conduct organizational behavior through community's scanning, advocating, and meeting public needs (Grunig, 2006). Tanner et al. (2012) reported that good public relations efforts can help a corporate to create customers' relationships, promote what it has to offer, and accomplish its sales efforts. Public relations place a positive spin on news stories and is often perceived as more neutral and objective than other forms of 
promotion because much of the information is customized as if it was created by a seller-independent organization.

Lamb et al. (2001) affirmed that Public Relations is the marketing communication function which is responsible for fulfilling a combination of programs which are designed to acquire public understanding and acceptance. Hence, it should be considered as an important aspect of the global marketing effort. Wilcox et al. (2005) reported that according to a study issued by the Public Relations Society of America (PRSA), the fundamental components of public relations include: Counseling, Research, Media relations, Publicity, Employee/member relations, Community relations, Public affairs, Government affairs, Issues of management, Financial relations, and Marketing communication.

\section{The role of public relations in the hotel marketing}

As with any marketing activity, public relations are integrated with the rest of promotional efforts of the organization and it is clearly related to more widespread objectives of the entity itself. Belch et al. (2001) pointed out that public relations has such an important role to play through the following points which are: Credibility, Cost, Avoiding the clutter, Ability to reach specific groups, and Building the image of the hotel.

Whereas, Marconi (2004) and Sachs (2003) denoted that the role of public relations in the marketing mix is plain and simple, key messages are communicated to defined target audiences within the marketing chain to influence purchasing decisions in order to enhance both of internal and external relationships. The same could be said of all the communicating disciplines of marketing. Consequently, Wilcox et al. (2005) agreed with Wetch (1994) that despite debating, the organization needs a cooperated and integrated communications strategy approach and all departments need to align their activities with the overall strategic goals of their organization. 
- The Effectiveness of Public Relations Activities in the Egyptian Hotels: An exploratory study

\section{The role of public relations in building hotel's image and reputation}

It is believed that hotel image plays an important role on customers in making the decision to use a hotel. Public relations are a major factor in the way the organization's image comes into focus. Because of public relations practitioners' important role in building and maintaining the image of their organization, they are often described as image- makers (Marconi, 2004).

Corporate image was identified as an important factor in the corporate's overall evaluation (Kandampully, et al., 2007). The concept of image places a premium on the quality of public relations messages which are sent from the organization and reported in the media (Leuven, et al., 2004).

Nguyen (2006) argued that once the customers hear the name of a firm, corporate image is what comes to their minds firstly. Because of the large intangible component of the hotel's offer, the association between corporate image and the offering of a hotel is much more difficult to identify. Therefore, it is imperative to render the intangible components tangible ones if the hotel is to communicate quality and value to its guests. Contact personnel and physical environment are thus used by many hotels, to successfully communicate the benefits, essentially creating a more concrete and perceivable image to its customers (Nguyen, 2006).

\section{Tools and techniques of public relations}

Traditionally, there are many tools that are used by the public relations practitioners, these tools can include: 1) Press releases: Saffir et al. (1994) highlighted, press releases are printing manuscripts, not business letters. Traditionally, the press releases consist of a one-page, brief summary of the essential facts behind a story (Brassington, et al., 2000). 2) Press conferences: Banik (2004) reported that public relations organize press conferences for building relations between the management 
and the media for appraisal on matters of public importance. 3) House journals: A house journal is an organization's official publication, highlighting its policies, programs, strategies and achievements. It is used to drive and motivate employees by explaining the management policies and programs to achieve better output and higher productivity (Banik, 2004). 4) Newspapers and Magazines: According to Cutlip et al. (2000), newspapers are considered the public information system's workhorse. When people think of publicity, they almost think of the newspapers instinctively. 5) Written materials: Public relations may use written materials to reach and influence their target audiences; including brochures, newsletters and annual reports of the organizations (Kotler et al., 2001). 6) Radio and Television: Henslowe (2003) pointed out that since radio and television have the widest influence on the public, they have become the most powerful media available for public relations. 7) Audio-visual media films: Marconi (2004) stated that audiovisual media are extremely convenient in public relations communications with the target audience. Public relations utilize this media to appeal all the target groups with good impact and credibility. 8) Exhibitions: Exhibitions are a powerful tool of public relations to create the awareness about the organization, and to give the participants the opportunity to contact face-toface. 9) Internet: Wright (2001) stated that the internet has grown into an extremely powerful communication medium which public relations professionals simply cannot ignore by utilizing its unlimited potential.

\section{The Activities of Public Relations}

\section{Media Relations:}

Schmitz (2012) stated that the media relations activity is probably the most visible part of public relations that an organization carries out because it deals directly with external media. Media relations activity is a largely technical function 
which means it is based on the technical ability to produce materials, or outputs of public relations. Regarding the conceptualization of media relations theory, Zoch et al. (2006) debated on the role which practitioners of public relations play in the agenda-setting theory when they try to share positive news stories about their organizations in media outlets. Sissons (2012) also found that journalists are not rigorously - or even halfheartedly - investigating news releases as they once did - most likely because of time and money limitations.

E-mail is critical in media relations. Like journalists and broadcasters, bloggers would prefer e-mail pitches to all other forms of media relations communication (Burns, 2008). Moreover, previous researches pointed out that most major corporations and most governmental agencies have web sites; nevertheless, there is often a lack of the provided information in an online newsroom (Alfonso, et al., 2006). Additionally, social media are used extensively. Sweetser et al. (2008) defined social media as "being focused on the concept of a read-write web, where online audiences move beyond passive web content viewing to actually participating in developing the content".

\section{Sponsorship:}

It was asserted that "sponsorship has its own genuine place in the marketing mix and is seen as offering particular advantages which support and enforce the work of public relations" (Collard, 2003). It is important to sponsor the organization's image in order to link this image with community groups and maintain the image and reputation of the organization (Nelson, 2004).

\section{Special Events:}

Kotler et al. (2001) pointed out that there are many different special events; hence, they include seminars, press conferences, press tours, receptions, grand openings...etc. Public relations use special events to capture the media attention to gain more media coverage, advertising and publicity. 


\section{Lobbying:}

Wood (2004) defined lobbying as "any attempt to influence the governmental institutions' decisions". Schmitz (2012) suggested that an external lobbying firm could also be hired, as an auxiliary to the corporation's government relations or public affairs unit. Lobbyists normally have expertise with the industry which is hiring them to communicate, build and maintain relations with legislators, press secretaries, and other governmental representatives.

\section{Crisis Management}

Achammara (2008) reported that the role of public relations in crisis management should not be understood only through the process of contact, which is considered as the basis of the public relations work. As an important factor of crisis management, the contact is essential in case of dealing with the crisis. Alzahrani (2016) also argued that crisis communication involves all the communications activities and roles which are practiced within the different stages of the crisis and falls within the framework of all kinds of contact activities.

\section{Corporate Social Responsibility (CSR)}

Sometimes the functions of donating funds or services strategically and an endeavor of corporate social responsibility are part of the efforts of public relations department. PR activity which is responsible for this reporting, is usually called the CSR unit or department and often is related to or managed by community relations (Schmitz, 2012). Moreover, Reeves (2016) indicated that in applied professional practice, there is an active role for public relations and also a variety of approaches to involving public relations in CSR programs.

Dahlsrud (2008) stated that The European Commission (EC) defines CSR as "the companies' process of integrating social and environmental factors into their business strategy and interacting with stakeholders voluntarily", however; the EC 
concept somehow overlooks the importance of economic development, which is the major concern in corporate operations.

A study by De Grosbois (2012) evaluated CSR reporting practice among the world's top 150 largest hotel firms. It showed that, "while a large number of companies are reporting commitment to CSR objectives, much smaller number of them are providing details of particular initiatives and reporting actual achievements. However, 109 of the world's largest 150 hotel companies reported some information related to the five main sustainability themes (environment, quality of employment, diversity and accessibility, community well-being, and economic prosperity). For example, 54 companies stated that they are committed to specific goals such as enhancing the quality of life of local communities.

There are three pillars of Corporate Social Responsibility. The economic area is the first pillar. The goal of doing business in general, as well as applies to the hotel business, is to achieve constant profit and long-term growth of the company's share price, and thus enables the hotels to fund and support a range of activities reported under CSR (Merhaut, 2013). The second of the pillars is the social factor, or a decent approach to employees or the region's development and promotion. These are some of the few issues that are addressed by the social pillar (Carroll, 2008). In the context of culture, education and safety, this path leads to positive understanding and development. Every socially responsible company should strive for principles that are consistent with the employees' health and safety, accept working standards and allow identical opportunities for all without any distinction between gender, age and ethnicity (Mervart, 2010).

Environmental pillar is the third and the youngest of all CSR pillars and the companies' goals are to minimize their energetic impact on society, and therefore on the environment. Awareness of the consequences of the activities to which the 
company commits should be part of each company's CSR policy. In other words, awareness of the environmental impact and waste economy that is ecological understanding within a company that is socially responsible. Companies are in direct contact with environmental protection organizations in this area (Merhaut, 2013).

Dyrtr (2006) mentioned that CSR and the hospitality industry have only been united for a short time, so the hotel facilities' owners and operators are beginning to be aware of the positive and the negative sides. There are many advantages which the CSR concept brings for the hotel industry. Pavlik (2010) argued that it is impossible to identify precisely how the invested funds and returns are related to each other; nevertheless there is no doubt that CSR activity has brought constancy and prosperity for a long time, while emphasizing that the financial perception of prosperity is not needed. It must be recognized that however, a significant fraction of other authors believes that while it is often almost impossible to find a profit, long-term benefits of brand values, relationships with stakeholders or reputation are incontrovertible concepts which CSR policies influence directly. Mervart (2010) asserted that the result of the adopting CSR policies is not just financial income. According to Mervart (2010), hotels nowadays do not only follow economic indicators but also search for social relationships, whether between employees and management or between the hotel and its publics. The first argument is the moral contribution that reflects the company's genuine awareness, where it could not afford to make a profit which is the core objective and principle of the hotel without the society in which the hotel operates (Kasparova, 2011). Another important aspect is to maintain a good quality of staff and recruitment; therefore, in other words, to increase the reputation and attractiveness of the company resulting in the increased interest among job seekers, in particular, the ones who 
- The Effectiveness of Public Relations Activities in the Egyptian Hotels: An exploratory study

are talented (Sawitz, 2013). The third aspect is that CSR increases both employees and customers' loyalty as well. This loyalty is followed by an increase in revenue which is frequently described as the correlation between customer loyalty and the hotel's CSR concept (Fiala, 2005).

\section{Methodology}

The aim of this research is to study the effectiveness of public relations activities in the Egyptian hotels. The study is limited only to four and five-star hotels in Greater Cairo. According to the Egyptian Hotel Association (EHA) (20152016), the total number of the hotels in Greater Cairo are around 185 hotels. There are 51 hotels categorized as five- and four-star hotels, therefore the study population represents $27.6 \%$ of all hotels in Greater Cairo.

Convenience sampling is the sampling method which was used in this research. The researcher conducted twenty two interviews at five-star and four-star hotels, with a percentage of $43.14 \%$ of total population. Twelve hotels out of 29 five-star hotels were the sampled from the five-star hotels, with a percentage of $41.38 \%$, while, the researcher conducted the interview only at 10 hotels out of 22 four-star classified hotels with a percentage of $45.45 \%$.

Primary data for this study was collected through interview with semi-structured interview form. The interview was conducted with a representative of public relations' practitioners in each hotel. The interview form was developed based upon the relevant review of literature.

The interview form was designed in this study to investigate the perspective of PR practitioners or experts in the hotel industry regarding the importance, usage and impacts of PR \& CSR activities in Greater Cairo hotels. The interview form included two types of questions (closed\& open) in order to get the most accurate answers and results. The interview form 


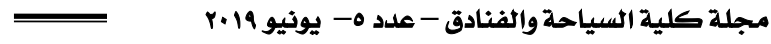

consisted of two parts. The first part addressed personal variables; including age, gender, education, department, position $\&$ years of experience. The second part explored the interviewees' perspectives

The conducted interviews took nearly four months (October, 2018 till February, 2019). The interviews were conducted personally with a sample $(\mathrm{N}=22)$ of employees. The interview form was designed in English language (Appendix A). The results obtained from the interviews were statistically analyzed whenever needed using SPSS (version 20). Data and information found in the study were analyzed and discussed in accordance with the stated objectives.

\section{Results and Discussion}

Part One: Personal Data Analysis

Table1. Employees' personal data analysis:

This section is concerned with the personal data of the respondents including age, gender, education, department where they were working, position and years of experience.

\begin{tabular}{|c|c|c|c|}
\hline \multicolumn{2}{|c|}{ Personal Data } & Freq. & $\%$ \\
\hline \multirow[t]{4}{*}{ Age } & From 25 to less than 30 years old & 10 & 45.5 \\
\hline & From 30 to less than 40 years old & 8 & 36.4 \\
\hline & From 40 to less than 50 years old & 1 & 4.5 \\
\hline & and more & 3 & 13.6 \\
\hline \multirow[t]{2}{*}{ Gender } & Male & 4 & 18.2 \\
\hline & Female & 18 & 81.8 \\
\hline \multirow[t]{2}{*}{ Education } & Bachelor's Degree & 19 & 86.4 \\
\hline & Master's Degree & 2 & 9.1 \\
\hline
\end{tabular}


- The Effectiveness of Public Relations Activities in the Egyptian Hotels: An exploratory study

\begin{tabular}{|l|l|l|l|}
\hline \multirow{4}{*}{ Department } & PHD Degree & 0 & 0 \\
\cline { 2 - 4 } & Other & 1 & 4.5 \\
\cline { 2 - 4 } & Mublic Relations & 1 & 4.5 \\
\cline { 2 - 4 } & Marketing & 8 & 36.4 \\
\cline { 2 - 4 } & Sales\& Marketing & 2 & 9.1 \\
\cline { 2 - 4 } & Front Office & 9 & 41 \\
\cline { 2 - 4 } & Human Resources & 1 & 4.5 \\
\hline Position & Manager & 1 & 4.5 \\
\cline { 2 - 4 } & Coordinator & 18 & 81.8 \\
\cline { 2 - 4 } & Executive & 2 & 9.1 \\
\hline Years of & Less than 5 years & 2 & 9.1 \\
\cline { 2 - 4 } & From 5 to less than 15 years & 9 & 40.9 \\
\cline { 2 - 4 } & From 15 to less than 25 years & 0 & 0 \\
\cline { 2 - 4 } & 25 years and more & 3 & 13.6 \\
\hline \multirow{4}{*}{ experience } & & & \\
\hline
\end{tabular}

Table 1 shows the profile of the interviewees in the investigated hotels. Regarding interviewees' age, the result shows that $45.5 \%$ of all the respondents were in the age between 25 and 30; followed by the respondents whose were in the age between 30 and 40 years with a percentage of $36.4 \%$. On the other hand, only $4.5 \%$ of them were in the age between 40 and 50 years; while, $13.6 \%$ of all the respondents were having more than 51 years old. 
Also, it is noticed that $18.2 \%$ of all the respondents were males compared to $81.8 \%$ were females. This means that the majority of interviewees are females.

In addition, to show the interviewees' educational level, table 1 presents that $86.4 \%$ of all the respondents were having a bachelor's degree; while, $9.1 \%$ of them were having a master's degree. On the other hand, $0 \%$ of them were having a $\mathrm{PhD}$ degree and $4.5 \%$ were having another degree.

Besides, it is observed that $4.5 \%$ of the interviewees were working at public relations department; while, $36.4 \%$ of them were working at marketing \& communication department. At the same time, there were $9.1 \%$ of them working at marketing department. Also, $41 \%$ of them were working at sales\& marketing department; followed by interviewees who were working at front office department with a percentage of $4.5 \%$. As well, there were $4.5 \%$ of them working at human resources department.

Furthermore, table 1 presents the interviewees' positions at the investigated hotels. Whereas $81.8 \%$ of them were managers, $9.1 \%$ of them were coordinators and $9.1 \%$ of them were executives.

Moreover, regarding years of experience of these interviewees, $45.5 \%$ of the interviewees were having less than 5 years of experience. While, $40.9 \%$ of them were having experience from 5 to 15 years. On the other hand, none of them was having experience from 15 to 25 years. And only $13.6 \%$ were having more than 25 years of experience.

When the interviewees were asked about the main objectives of PR department in their hotel, $40.9 \%$ mentioned that the main objective is to highlight the brand image and maintain a high position for the hotel. While $27.3 \%$ said that the PR's main objective is to promote the hotel's facilities and convey the hotel's facilities and convey the hotel's key messages. Additionally, 
there are $9.1 \%$ of the interviewees who pointed out that managing crisis effectively is the main objective of PR. Besides, 9.1\% stated that the PR's objective is to ensure that the hotel supports the community. Furthermore, $13.6 \%$ cited that the main objective of PR is to be present in the market.

When the researcher asked them to indicate the importance of the following PR Activities (Media relations, Sponsorship, Special events, Lobbying, Crisis management, Philanthropy and Corporate social responsibility), Media relations is the most important activity of Public Relations between the other activities with a mean of (4.77). These findings agreed with Schmitz (2012) who stated that the media relations activity is likely the most visible portion of public relations that an organization conducts because it deals directly with external media; while, sponsorship is the least important activity between the other activities of PR with a mean of (3.23). These findings disagreed with Nelson (2004) who mentioned that sponsorship is important to link the organization's image with community groups and restore the organization's image and reputation.

When they were asked about the PR tools they use to reach the main objectives at this hotel (Press releases, Press conferences, House journals, Newspapers and magazines, Written materials, Radio\& Television, Audio-visual media films, Exhibitions, Internet), Internet had the highest average of usage between the other tools with a mean of (5); hence all the hotels always use this tool. On the other hand, Radio\& Television had the lowest average of usage between the other tools of PR with rated average (2.36).

When they were asked to indicate the importance of the following PR tools (Press releases, Press conferences, House journals, Newspapers and magazines, Written materials, Radio\& Television, Audio-visual media films, Exhibitions, Internet), the majority of the interviewees gave internet the priority of 
importance with a mean of (5). These findings are supported by Wright (2001) who stated that the internet has grown into an extremely powerful communication medium which public relations professionals simply can't ignore, and Ibrahim (2006) who mentioned that in recent years the internet has been become one of the most powerful public relations tools. Nevertheless, the minority stated that press conferences had the lowest average between other tools with a mean of (3.18). These findings disagreed with Bland (2004) who highlighted that press conferences are ideal for events or announcements of major importance.

When the interviewees were asked whether they conduct any PR campaigns or not, $95.45 \%$ of the interviewees conducted PR campaigns such as new services\& facilities launching campaigns and organizing special events for bloggers. While, only $4.55 \%$ of them didn't conduct any PR campaigns and they mentioned some examples of these campaigns such as: new services\& facilities launching campaigns, offering free vouchers for loyal guests, creating media influencers' family programs, organizing special events for bloggers, and organizing dinner gatherings for the accounts with whom the hotels are dealing.

When the researcher asked interviewees about having good relations with media representatives, it's stated that $100 \%$ of the interviewees have good relations with media representatives because they can spread the hotel's image and reputation, media representatives are the link between the hotel and its targeted audiences, they can spread the hotel's image and reputation, they can highlight the hotel's activities and events, and they promote the hotel's facilities and services for free. However, none of them said that they don't have good relations with media representatives.

When they were asked if they think media covers PR activities in their hotel effectively, the researcher found out that 
$90.91 \%$ of the interviewees do think media covers PR activities in their hotels effectively. On the other hand, $9.09 \%$ did not think so. Some of media that were given as they were dealing with are: Egypt Today journal, Classy magazine, Identity magazine, Insight magazine, Enigma magazine, Akhbar journal, Algomhouria journal, and Lady Bird magazine.

When they were asked to rank the media channels (Journalism, E-mails, Websites, Social media) their hotels use to reach most of the targeted groups, social media had the highest average of usage between the other channels with a mean of (5). On the other hand, journalism had the lowest average of usage between the other media channels with a mean of (3.86).

When the researcher asked them to rank the importance of media channels (Journalism, E-mails, Websites, Social media) from their point of view, social media is the most important media channel between the other channels with a mean of (5). These findings agreed with Sweetser, et al. (2008), who mentioned that it is important because it allows readers and observers to interact, contribute, and build on the content presented by organizations. In contrast, journalism is the least important channel between the other media channels with a mean of (3.68). These findings agreed with Sissons (2012), who found that as the number of public relations professionals increases and the number of journalists, and Tsetsura, et al. (2017), who noted that as media transitioned into a new age, the relationship between public relations and journalism changed. On the other hand, these findings disagreed with Tsetsura, et al. (2018), who stated that Journalists recognize that public relations play a vital role as an information subsidy.

When the interviewees were asked whether their hotels are involved in the community's issues or not, the statistics showed that major hotels involved in the community's issues as poverty, health, educational, environmental, and animal abuse issues with 
the percentage $95.45 \%$. While only $4.55 \%$ did not involve in the community's issues.

When they were asked if their hotel participates in charitable activities of the community, the study found out that the majority, which is represented with $95.45 \%$, participated in charitable activities of the community such as donating for Brooke Hospital for Animals, Abo Elrish Hospital, Egyptian Food Bank, 57357 Hospital, Egyptian Clothing Bank, Egyptian Red Crescent, and Dar Elamal Orphanage.; while, the minority, which is represented with $4.55 \%$ didn't participate in these charitable activities.

When the researcher asked the interviewees if their hotel supports educational institutions, their answers figured out that $77.27 \%$ of the hotels supported educational institutions like offering summer trainings for students of faculties of tourism and hotels, supporting Y.G.I School, Sponsoring I.H.G Academy, and offering free vouchers for the outstanding students from Gerard French School; while $22.73 \%$ of them didn't support any educational institutions.

By asking them whether they enhance the quality of life in the society or not, the findings pointed out that the minor number of hotels enhanced the quality of life with the percentage of $36.36 \%$ such as offering computers for governmental schools, cleaning the area around the hotel, renovating the road around the hotels, renovating Cornish $\mathrm{El}$ Nile in front of the hotel, and building a bridge in front of the hotel. Nevertheless, the major number of hotels which represents $63.64 \%$ didn't enhance any kind of the quality of life and they mentioned that it is not too important manner to take in their account.

When asking them if their hotel supports activities related to sustainability, the findings showed that $90.91 \%$ of the hotels support activities related to sustainability as applying In-house guests awareness programs, being engaged in green programs, 
and recycling wastes inside the hotel itself; while, just $9.09 \%$ don't support any activity related to sustainability because it costs too much to support such activities and their benefits are less than such costs.

In addition, $81.82 \%$ of the investigated hotels operates in a manner consistent with ethical values and norms of the society. These findings agreed with Lorenc (2016) who explained that hotel companies finance a whole range of socially responsible activities. .The interviewees mentioned the following:

Three hotels out of these eighteen hotels built a mosque for guests and employees; while all the eighteen hotels applied Code of Conduct for employees and guests both. Two hotels did not serve any alcoholic beverages.

When the researcher asked them about the frequency of allocating budget for PR activities, the majority was always allocating budget for PR activities with a mean of (4.091)

By asking the interviewees to rate the sufficiency of the allocated budget of PR, "yes very sufficient" had the biggest number of choices among other choices with a mean of (2.727). On the other hand, "not sufficient at all"\& "slightly sufficient" had the smallest number of choices among the others with a mean of 0 . Moreover, there were missing chooses as a result of never allocating budget with a mean of (0.091).

When asking them whether they have specific criteria for evaluating the effectiveness of PR activities in their hotels or not, the findings indicated that most of interviewees had specific criteria to evaluate the effectiveness of PR activities in their hotels with the percentage $95.45 \%$.

Nine interviewees out of twenty one depended on annual reports; while three of them evaluated PR activities by number of press releases. Also, four interviewees measured the R.O.I. which stands for return on investment. In addition, fourteen of them depend on the income of a specific PR campaign. Likewise, one 
interviewee monitored the reach of the hotel over social media channels. Besides, two of them evaluated PR effectiveness by using guests' feedback cards. As well, two of them measured G.R.R... As a plus, one of them monitored the hotel's presence in the market. Further, one of them measured the volume of business generated after PR campaign.

While just $4.55 \%$ mentioned that they did not have any criteria for evaluating PR activities and when the interviewees who mentioned that there were not any criteria for evaluating the effectiveness of PR activities was asked about how they could evaluate the effectiveness of these activities, they stated that PR activities cannot be measured but its effectiveness could be predicted by monitoring the increase of the income after a PR campaign using a specific tool.

When the interviewees were asked if they think these PR \& CSR activities have impact on the image and reputation of the hotel, $100 \%$ of the interviewees did think these PR\& CSR activities have impact on the image and reputation of the hotel either by spreading a good word of mouth about the hotel, increasing the awareness about the hotel and its brand name or showing how much the hotel cares about the community,'. When they were asked to explain how these activities affect the image and reputation of their hotel, one interviewee out of twenty two mentioned that PR\& CSR activities affect the hotel's image\& reputation by spreading a good word of mouth about the hotel; while two interviewees of them pointed out that these activities maintain a high position for the hotel. Also, eight of them added that PR\& CSR activities increase the awareness about the hotel and its brand name. At the same time, eight of them stated that these activities show how much the hotel cares about the community. In addition, three interviewees figured out that PR\& CSR activities can get the guest trust in the hotel. Besides, one of them mentioned that these activities shed the light on the 
strengths of the hotel. Likewise, two interviewees stated that these activities show how powerful, active, and be involved in the community's issues the hotel is. As a plus, two of them added that these activities show how the hotel supports the community. Furthermore, four of them mentioned that these activities encourage guests to share their reviews over social media. Moreover, three interviewees explained that these activities make the brand name repeatable in many occasions.

When they were asked whether they think these PR \& CSR activities have impact on the hotel competitive advantage, $100 \%$ did think that PR\& CSR activities have impact on the hotel's competitive advantage either as the targeted audience will be more likely to choose the hotel where PR \& CSR activities are done, or as the current guests will use more services inside the hotel itself to be part of the community. Twenty interviewees out of twenty two mentioned that the targeted audience will be more likely to choose the hotel where PR \& CSR activities are done. As a plus, eleven interviewees of them added that the current guests will use more services inside the hotel itself to be part of the community.

When the interviewees were asked to mention their suggestions and recommendations to enhance PR activities in the hotel industry, six interviewees out of twenty two recommended that PR should be an independent department. Also, six interviewees of them suggested allocating more enough budget for PR campaigns and activities; while only one of them recommended dealing with local airlines as a kind of lobbying. On the other hand, focusing more on social media bloggers\& was strongly recommended by nine interviewees. In addition, one interviewee recommended that PR practitioners should focus more on media relations. Similarly, one interviewee of them suggested focusing more on editorials\& press releases. As a plus, two interviewees recommended that they should be updated. two 
of them added that they must be creative as much as they can. Besides, two interviewees mentioned that PR employees should have proven experience or backgrounds of PR. Additionally, it was suggested to decrease using written materials by only one interviewee. Furthermore, one interviewee suggested using mobile apps as a PR tool.

\section{Conclusion and Recommendations \\ Conclusion}

This study investigated the effectiveness of PR activities in a sample of hotels in Greater Cairo. The study, extensively reviewed the related literature on the topic of $\mathrm{PR}$, tools of PR, activities of PR, the hotel's image and reputation, Media Relations and CSR activities attempted to evaluate the significant impact of PR activities on hotel's image, reputation and competitive advantage. In this research, two research objectives were set to accomplish the aim of the study. The first objective was achieved through undertaking a critical analysis of relevant literature on PR and its tools \& activities. As well as, it explored the PR with various definitions, its dimensions, process, functions, tools \& techniques, role and activities.

The second objective was achieved through semistructured interviews conducted with a convenience sample of four-star and five-star hotels. Interviews were conducted with 22 PR practitioners in the selected hotels.

The findings indicated that the majority of respondents were between 25 and 30 years old. Most of them were females. The major interviewees were having bachelor's degree. Most of them were working at marketing \& communication department. The majority were managers. Most of them were having less than 5 years of experience.

In terms of Public Relations activities' importance, the activity "media relations" was the most important activity of 
= The Effectiveness of Public Relations Activities in the Egyptian Hotels: An exploratory study

Public Relations and the activity "sponsorship" was the least important activity.

The tool "Internet" had the highest frequency of usage with a mean of (5); while, the tool "Radio\& Television" had the lowest frequency of usage with a mean of (2.36), and regarding the importance of these tools, the tool "internet" was the most important with a mean of (5); while, the tool "press conferences" was the least one with a mean of (3.18).

In the term of PR campaigns, many of the interviewees, with a percentage of $95.45 \%$, conducted PR campaigns and most of them were depending on new services\& facilities launching campaigns.

In terms of media relations \& coverage, all the interviewees had good relations with media representatives, and most of them stated that it is because media representatives can spread the hotel's image and reputation. Concerning media coverage, the major interviewees thought that media covers PR activities effectively with a percentage of $90.91 \%$. Many of them were dealing with Egypt Today magazine.

In terms of media channels, the channel "Social Media" was used the most with a mean of (5); while the channel "Journalism" was used the least with a mean of (3.86). With reference to these channels' importance, Social Media had the highest average compared with the other channels with a mean of (5), and Journalism had the lowest average mean compared with the other media channels with a mean of (3.68).

In terms of corporate social responsibility, many of the hotels did involve in the community's issues with a percentage of 95.45\% like poverty, health, education, social and environmental issues; hence, many of them involved in poverty issues. Also, in terms of charitable activities, the major hotels participated in charitable activities with the percentage $95.45 \%$. Additionally, in terms of educational institutions, the majority of the hotels 
supported educational institutions with a percentage of $77.27 \%$. Regarding the quality of life, many of the hotels did not enhance the quality of life with the percentage $63.64 \%$. Further, in terms of sustainability, the major hotels supported activities related to sustainability with a percentage of $90.91 \%$. Moreover, in terms of ethical values of the society, the majority of the hotels did operate in a manner consistent with ethical values and norms of the society with the percentage $81.82 \%$.

In terms of PR budget, the majority of the interviewees were always allocating budget for PR activities with a mean of (4.091). In addition, concerning the sufficiency of this budget, the answer "yes very sufficient" had the highest average among other answers with a mean of (2.727).

In terms of evaluating the effectiveness of PR activities, many of interviewees had specific criteria to evaluate the effectiveness of PR activities in their hotels with the percentage $95.45 \%$.

In terms of the impact of PR\& CSR activities, all of the interviewees did think that PR\& CSR activities have impact on the image and reputation of the hotel with a percentage of $100 \%$. As well as, all the interviewees thought that PR\& CSR activities have impact on the hotel's competitive advantage with the percentage $100 \%$.

Concerning the interviewees' recommendations and suggestions, the interviewees strongly recommended that the hotel management should focus more on social media bloggers\& influencers as a PR tool.

\section{Recommendations}

Depending on the literature review and the research findings, it could be suggested that hotels executives should consider PR activities as any other decision when putting policy and applying strategies in order to spread the hotel's image and reputation. PR should be used as a marketing tool to maintain the 
- The Effectiveness of Public Relations Activities in the Egyptian Hotels: An exploratory study

current guests and attract more targeted audiences. The hotel managers should encourage their guests to participate in CSR activities by increasing their awareness regarding CSR activities so that they can feel they are a part of the community. Four-star hotels should focus more on CSR activities as one of the most important activities of PR. Moreover, these hotels need to employ independent PR specialists at the hotel itself in order to make professional action plans for PR and apply these plans effectively.

${ }^{1}$ Master Researcher Faculty of Tourism and Hotels - Mansoura University

${ }^{2}$ Ass. Prof of Hotel management- Faculty of Tourism and Hotels - Mansoura University 


\section{References}

Achammara, A. (2008). The role of public relations in address security crises, Alain: Session scientific.

Alfonso, G.-H., \& Miguel, R. (2006). Trends in online media relations: Web-based corporate press rooms in leading international companies. Public Relations Review, 32(3), 267275.

Alzahrani, F. (2016). The Role of Public Relations in Organizational Crisis Management, International Journal of Scientific \& Engineering Research,7(1), 1075-1086.

Banik, G. (2004). Effective Public Relations in Public and Private Sector, Jaico Publishing House, Mumbai.

Bates, D (2006). "Mini-Me" History Public Relations from the Dawn of Civilization,_Copyright $\odot$ 2006, Don Bates Published by Institute for Public Relations www.instituteforpr.org.

Belch, G. \& Belch, M. (2001), Advertising and Promotion: An Integrated Marketing Communication Perspective, $5^{\text {th }}$ ed., McGraw-Hill Irwin, New York.

Bland, M. (2004). Effective Media Relations, Pearson Education, Inc., New York.

Brassington, F. \& Petit, S. (2000). Principles of Marketing, $2^{\text {nd }}$ ed., Prentice Hall Inc., New Jersey.

Broom, G. (2009). Effective public relations $10^{\text {th }}$ ed., Upper Saddle River, N.J.: Pearson Prentice Hall.

Bruning, S. \& Ledingham, J. (2000). Explicating Relationship Management as a General Theory of Public Relations. Journal of Public Relations Research, 15(2), 181-198.

Burns, S. (2008). A historical examination of the development of social media and its application to the public relations industry. Paper presented the International Communication Association conference, Montreal. 
Carroll, A. (2008). The Pyramid of Corporate Social Responsibility. 1st ed. London: Routledge.

Cutlip, S., Center, A. \& Broom, G. (2000). Effective Public Relations $8^{\text {th }}$ ed., New Jersey: Prentice Hall.

Daft, R. (2001). Organizational theory and design, Southwestern College Publishing: NY.

Dahlsrud, A. (2008). How corporate social responsibility is defined: an analysis of 37 definitions. Corporate Social Responsibility and Environmental Management, 15(1), 1-13.

De-Grosbois, D. (2012). Corporate social responsibility reporting by the global hotel industry: Commitment, initiatives and performance. International Journal of Hospitality Management, 31(3), 896-905.

Dyrtr, Z. (2006). Good business name. 1st ed. Prague: Alfa Publishing.

Fiala, P. (2005). Information Sharing in Supply Chains. Thousand Oaks, CA: Sage.

Grates, G. (1995). Are You Ready to Grow? Communication Strategies for Managing Growth in A Complex and Competitive Market Place, Public Relations Quarterly, 40(3), 42-46.

Grunig, J. (2006). Furnishing the Edifice: Ongoing Research on Public Relations as A Strategic Management Function. Journal of Public Relations Research, 18(2), 151-176.

Grunig, L., Grunig, J. \& Dozier, D. (2002). Excellent public relations and effective organizations: A study of communication management in three countries. Mahwah, NJ: Lawrence Erlbaum.

Henslowe, P. (2003). Public Relations: A Practical Guide to The Basics, Crest Publishing House, New Delhi.

Ibrahim, E. (2006). Evaluating the Role Public Relations in Marketing Activity of Cairo Hotels, Master's Thesis, Faculty of Tourism and Hotel Management, Helwan University. 
Jethwaney, J. \& Sarkar, N. (2000). Public Relations., New Delhi: Sterling.

Kandampully, J. \& Hui, H. (2007). Do hoteliers need to manage image to retain loyal customers?. International Journal of Contemporary Hospitality Management, 19(6), 435-443.

Kašparová, K. (2011). Corporate Social Responsibility Reporting. 1st ed. Brno: Masaryk University Brno.

Kotler, P. \& Armstrong, G. (2001). Principles of Marketing, $9^{\text {th }}$ ed., Prentice Hall Inc., New Jersey.

Lamb, Ch., Hair, J. \& McDaniel, C. (2001). Essentials of Marketing, $2^{\text {nd }}$ ed., SouthWestern College Publishing, Ohaio.

Lawrence, A., \& Weber, J. (2014). Business and Society: Stakeholders, Ethics, Public Policy $14^{\text {th }}$ ed., New York, NY: McGraw-Hill., ISBN9780078029479.

Leuven, J. \& Mak, A. (2004). Reformulating Organizational Identity and Reputation Theory from A Public Relations Vantage Point, $7^{\text {th }}$ International Public Relations Research Conference, South Miami, Florida, USA.

Lorenc, M. (2016). Corporate Social Responsibility in the Hospitality Industry: A qualitative study on the perception of CSR and its activities. (Unpublished master's thesis). Tourism Master, Program, $10^{\text {th }}$ Semester. Aalborg University. Denmark: Scandinavia.

Marconi, J. (2004). Public Relations: The Complete Guide, Thomson Learning, Inc., Ohio.

Merhaut, M. (2013). Ethics as a part of corporate social responsibility. 1st ed. Prague.

Mervart, R. (2010). Corporate Social Responsibility - A guide for not only small businesses. 1st ed. Prague: TOP Partners.

Nelson, K. (2004). Marketing Public Relations Tactics and Programs, http://www.agda.asn.au/dm/observations/marke.html. 
Nguyen, N. (2006). The collective impact of service workers and service scape on the corporate image formation. International Journal of Hospitality Management, 25 (2), 227-244.

Pavlik, M. (2010). Corporate Social Responsibility. 1st ed. Prague: Grada.

Reeves, H. (2016). Defining Public Relations' Role in Corporate Social Responsibility Programs, PR Journal, 10(2), 1-19.

Sachs, M. (2003). Marketing Communication, In A. Gregori (Eds.), Public Relations in Practice: A Sector-By-Sector Guide, Crest Publishing House, New Delhi.

Saffir, L. \& Tarrant, J. (1994). Power Public Relations: How to Get PR to Work for You, NTC Business Books, New York.

Sawitz, A. (2013). Triple Bottom Line. 1st ed. UK: Jossey Bass Wiley.

Schmitz, A. (2012). Public Relations, http://lardbucket.org./.

Sissons, H. (2012). Journalism and public relations: A tale of two discourses. Discourse \&Communication, 6(3), 273-294.

Sweetser, K. \& Lariscy, W. (2008). Candidates make good friends: An analysis of candidates' uses of Facebook. International Journal of Strategic Communication, 2(3), 175198.

Tanner, J. \& Raymond, M. (2012). Principles of Marketing. (C)2012 Flat World Knowledge, Inc.2.

Tsetsura, K. \& Aziz, K. (2018). Toward professional standards for media transparency in the United States: Comparison of perceptions of non-transparency in national vs. regional media. Public Relations Review, 44(1), 180-190.

Tsetsura, K. \& Kruckeberg, D. (2017). Transparency, public relations and the mass media: Combating the hidden influences in news coverage worldwide. New York: Taylor and Francis/Routledge. 
Warnaby, G., Moss, D. \& Verčič, D. (2002). Perspectives on Public Relations Research, ebrary, Inc.

Wetch, S. (1994). Restaurant and Food Service Marketing into The $21^{\text {st }}$ Century, Journal of Restaurant and Food Service Marketing, 1(1), 1-19.

Wilcox, D., Cameron, G., Ault, P. \& Agee, W. (2005). Public Relations: Strategies and Tactics, $7^{\text {th }}$ ed., Pearson Education, Inc., New York.

Wood, E. (2004). Corporate Identity In Theaker, A. (Eds), The Public Relations Handbook, $2^{\text {nd }}$ ed., Routledge, New York.

Wright, D. (2001). The Magic Communication Machine: Examining The Internet's Impact On Public Relations, Journalism and The Public, The Institute for Public Relations, Florida.

Zoch, L., \& Molleda, C. (2006). Building a theoretical model of media relations using framing, information subsidies, and agenda-building. 